How to Cite

Pérez, A. V., Pomares, L. F., \& Gámez, M. R. (2020). Pinar Del Río geography and connected photovoltaic systems to the grid. International Journal of Life Sciences \& Earth Sciences, 3(1), 8-14. https://doi.org/10.31295/ijle.v3n1.139

\title{
Pinar Del Río Geography and Connected Photovoltaic Systems to the Grid
}

\author{
Liudmila Fuente Pomares \\ Universidad Tecnológica de la Habana, La Habana, Cuba \\ Corresponding author email: liudmila@electrica.cujae.edu.cu \\ Antonio Vázquez Pérez \\ Universidad Técnica de Manabí, Portoviejo, Ecuador \\ Email: antoniov5506@gmal.com \\ María Rodríguez Gámez \\ Universidad Técnica de Manabí, Portoviejo, Ecuador \\ Email: taliangel270557@gmail.com
}

\begin{abstract}
The affectations that are reported starting from the use of the petroleum in the energy production of the country in the economic and environmental, open an analysis space for the search of alternative sustainable in the electric generation, based on the employment of the renewable potential that exists in the territories. In these work analyzed the evaluation of the territorial space of the Pinar del Rio county was presented that can be used for the development from the connected photovoltaic systems to the grid. Like a viable energy alternative that propitiates the reduction of the environmental impacts and of natural disasters, at the same time that it constitutes an economically sustainable solution, when not having to incur in expenses of resources to acquire the fuel that today has used with those purposes. This county through the years, it has been impacted by phenomena hydrometeorology extreme reason by which you the program of the distributed generation with the objective of giving vitality to the electric service began. In the work it is demonstrated the possibilities of the use of the space for the development of central photovoltaic connected to the grid, offering the calculations of the capacity that it can settle in that territory, and with it to improve the vitality of the electric service in extreme situations.
\end{abstract}

Keywords---distributed generation, photovoltaic systems, solar potential, territorial ordination.

\section{Introduction}

The Territorial Planning plays an important role in the search for solutions of the problems caused by the human being in its interaction with the territory and the Geographic Information Systems (GIS) (Hachem et al., 2011; Voivontas et al., 1998), constitute a tool for the planning and management of the territories, with them to achieve greater balance and sustainability (Peña, 2005; Pérez et al., 2019). The planning of the territory is the spatial expression of the economic, social, cultural and ecological policy of the whole society, it is both a scientific discipline, an administrative technique, a policy conceived as an interdisciplinary and global approach, and which pursues objective is a balanced development of regions and the physical organization of space, as a guiding concept (Leeuwen, 2001; Suarez et al., 2018).

The planning of the territory is a discipline of a broad vision, which observes the space and serves as a tool to plan it, however small it may be. It puts this space in relation to other disciplines, allowing for approaches that go in the same direction, such as the concept of sustainable development: "meeting the needs of present generations, without compromising the possibilities of those of the future to meet their own needs (ONU, 1992). There is a close relationship between economy, society and nature, these are developed in the territory reflecting this concept in the

ISSN 2632-9425

Submitted: March 27, 2020 / Revised: April 09, 2020 / Accepted: May 18, 2020 
geographical image of the earth. There are regions that guide this objective through balanced and sustainable development based on the characteristics of the territory and on the national management of natural resources (BOE, 2004), regulated in guiding principles.

Improving the quality of life in society requires increasing economic development through technological innovation, creating new knowledge that humanizes work, that accelerates the processes of production and reproduction in an integral way and, therefore, increases the improvements in infrastructure and in the socioeconomic development. To achieve this increase it is necessary to extract material resources from nature, in a rational and sustainable way. The company is in constant interaction with the land management processes and its elements are the main client, its regulatory entity at the appropriate consumption levels and the controller, which at the same time energize these processes.

The processes and mechanisms are developed in the same space, this space is shared among all species, infrastructures, etc., it is where man develops his activities, it is in him, in which everything that is needed to achieve the desired quality of life; but it is also necessary to create the strategy of not destroying what exists, but exchanging and protecting what you have. The mechanisms of extraction and contribution must not be spontaneous, they must respond to designs and integrated management plans in the territory, which allow the recovery of what is extracted, based on the concept of renewal of the resources used. This is where the Territorial Planning contributes decisively to plan and sustainably manage resources over time (Niknam et al., 2003; Ghosh et al., 2010; Borges \& Falcao, 2006).

The Planet cannot supply the resources that are extracted indefinitely, so we are obliged to draw up strategic plans, using land management as a method and modeling geographic information systems, aimed at establishing energy self-sufficiency policies of the territories, at the expense of its resources and especially the renewable ones, achieving with the planning to promote the real development of the localities, compatible with rational exploitation of the resources, especially the non-renewable ones and the protection of the environment. When analyzing the geographical space, the processes and laws of space-related to these processes are studied. The methods used for spatial analysis are diverse, among them are statistics, cartography, statistical geo. Considering territorial planning within the framework of energy planning, as a public and technical planning process, which must be flexible, continuous and long-term, affecting the environmental, social, economic, political and administrative aspects where it is essential to evaluate the potential capacities of the territory to meet the growing demand for electricity for the improvement of the quality of life. In this work, digital mapping was prepared for the analysis of the appropriate energy systems for the development of grid-connected photovoltaic systems

\section{Materials and Methods}

To carry out the studies, the province's cartography had to be reorganized in 1: 100000 cartography, managing to select the existing cartographic elements of the old province of Pinar del Río and under these elements, the proposed study was carried out. It took into account parameters that from the technical and territorial point of view influenced the analysis of the use of space to implement the photovoltaic systems connected to the network (Mantuano et al., 2019; Arauz et al., 2017). For the solar evaluation, SWERA (Solar and Wind Energy Resource Assessment) project data was taken that provides easy access to high quality renewable energy resource information and data to users around the world. Its goal is to help facilitate renewable energy investment policy with freely available information. SWERA products include Geographic Information Systems (GIS) and time-series data, along with energy optimization tools (SWERA, 2009; Arauz et al., 2016). The information was used to design and punctuate the study by determining suitable areas with characteristics that do not affect the productive program of that territory for the implementation of the technology.

\section{Results and Discussions}

\section{Geographic location}

The Pinar del Río Province is located in the westernmost region of the country, between $21^{\circ} 45$ 'and $22^{\circ} 54^{\prime}$ north latitude and between $83^{\circ} 5$ 'and $84^{\circ} 58^{\prime}$ 'west longitude, to the north, it borders the Gulf of Mexico; to the East with the province of Artemisa; To the South, it borders the Caribbean Sea and the Gulf of Batabanó and to the West of the Yucatan Channel. It has an area of $8847.28 \mathrm{~km} 2$ and a population of 594560 inhabitants, of which $62 \%$ reside in urban areas, with a population density equivalent to 67 inhabitants per square kilometers. 
This territory depended on the Havana Council until 1774, on which the tenure of the government of New Filipina is founded, whose jurisdiction extended from the Los Palacios River to the Cabo de San Antonio. The head of the tenure and the seat of the government initially resided in Guane, then they pass to San Juan and Martínez and finally to Pinar del Río is 1778, the year in which the province was born by Royal Decree of July 23, issued by Felipe de Fon divert it, Marqués de la Torre and Captain-General of the Island (ONE, 2007; Castillo et al., 2016). Influencia de Los Componentes Climáticos. In recent years the average annual rainfall ranges between 1,441 $\mathrm{mm}$, with higher values in the municipalities of San Juan and Martínez and La Palma, since they register an annual average above the province. In the year there is an average of 135 days of rains distinguishing two periods, the first between the months from May to October where the greatest amount of rainfall occurs, and as a consequence of this climatic situation the relative humidity increases and the winds have a lower speed.

The second period extends between the months between November and April in which rainfall is scarce, temperatures tend to be lower, humidity decreases, and winds reach a higher speed. The average annual relative humidity is $78 \%$, the average cloudiness is $4 / 8$ and the prevailing winds are from the East with a speed of up to 7 $\mathrm{km} / \mathrm{h}$. The absolute maximum temperature is $34^{\circ} \mathrm{C}$ and the absolute minimum is $11^{\circ} \mathrm{C}$, with an average temperature of $22^{\circ} \mathrm{C}$. The geographical location of the province implies that it is occasionally hit by tropical cyclones, having been affected by 80 extreme hydrometeorological events of this nature, of which 23 have been of great intensity, 21 of moderate-intensity, and 36 of low intensity, it is considered.

\section{Main Sociopolitical Characteristics of the Province}

In 2011 the province underwent changes in its administrative political structure due to the division of the old province of Havana, where three of its municipalities passed to the subordination of the newly created province Artemisa. It has a broad profile of economic and productive lines, which include companies and state economic organizations whose social purpose is to meet social needs, which constitute the fundamental links of the organization and operation of the economy. It also includes cooperatives, Agricultural Production Cooperatives (CPA), Credit and Services Cooperatives (CCS) and Basic Units of Cooperative Production (UBPC). They are economic entities that represent an advanced and efficient way in the production of the province, standing out in agriculture, the cultivation of tobacco and sugar cane industry, cereals, vegetables, foodstuffs (tubers and roots) citrus, vegetables, fruit trees, as well as other crops.

It stands out in the production of milk and beef, as well as in the production of milk and meat of sheep and goats. In addition to the production of eggs and pig farms, among others. Tourism is in full development, reaching income indicators. As well as the education, health, and social assistance system, they extend throughout the whole territory, contributing to the development of the province. Figure 1 shows the map with the representation of the administrative political division currently made up of 11 municipalities. 


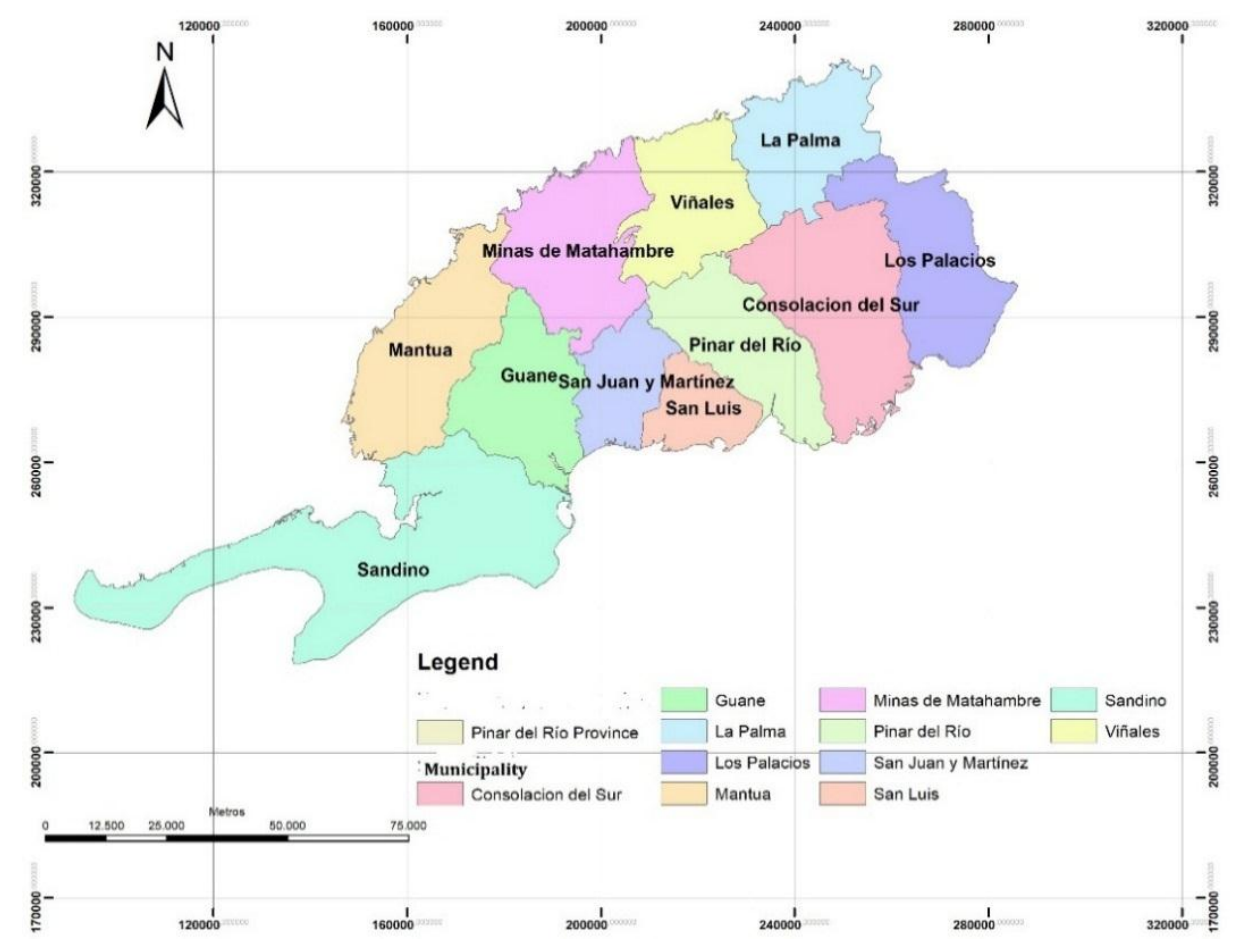

Figure 1. Map with the political-administrative division of the province of Pinar del Rio

\section{Energy Territorial Planning Analysis and Solar Potential Assessment}

Different parameters were assessed from the technical and territorial point of view that influenced the analysis of the possible use of the space to implement the photovoltaic systems connected to the network, as well as the evaluation of the solar potential in this territory (Mellit \& Benghanem, 2007; Keller \& Affolter, 1995; Hwang, 1997). In addition to considering the different parameters involved in the investment process for this technology. The information on the objectives that limit the use of the space for the investments of the Photovoltaic Plants was processed as they are; road networks, rivers, streams, dams, reservoirs, orography, bridges, agricultural uses, and other physical barriers.

An important aspect to highlight was the occupation of the soil by the different areas dedicated to agricultural uses such as: the cultivation of tobacco, cane, cereals, coffee, vegetables, food (citrus and tubers) citrus, vegetables, fruit, crops Rotating pastures and nurseries as well as other crops and the plant layer, these permanently occupy a total 520,625.42 ha. The stability of agricultural and agricultural production in the province depends on the use of these areas, so they constitute an immediate limitation for the installation of these systems and are therefore not considered viable areas for investments. The areas of artificial grass and grass occupy a total of 105,564.63 ha, which represent $12 \%$ of the total area of the province. Being used by the agricultural sector as a supply for farms and dairy farms in the province, so they also constitute a limitation for the installation of these systems, not being considered for investments.

There are other concepts associated with the land occupation that limit the development of photovoltaic systems connected to the network, such as: Protected Areas that permanently occupy a total of 185,531.50 ha and low-lying areas with a total of $71,325,84816$ ha. These areas that constitute a limitation for the development of photovoltaic systems connected to the network, represent $93 \%$ of the total territory of the province, there is a total of $61,930.96$ hectares that present viability for the development of these technologies. The municipalities that present greater viability of the land to undertake investments of the photovoltaic power plants connected to the network are Consolación del Sur and Viñales. Figure 2 shows the map with the viable areas for the development of photovoltaic systems connected to the grid. 


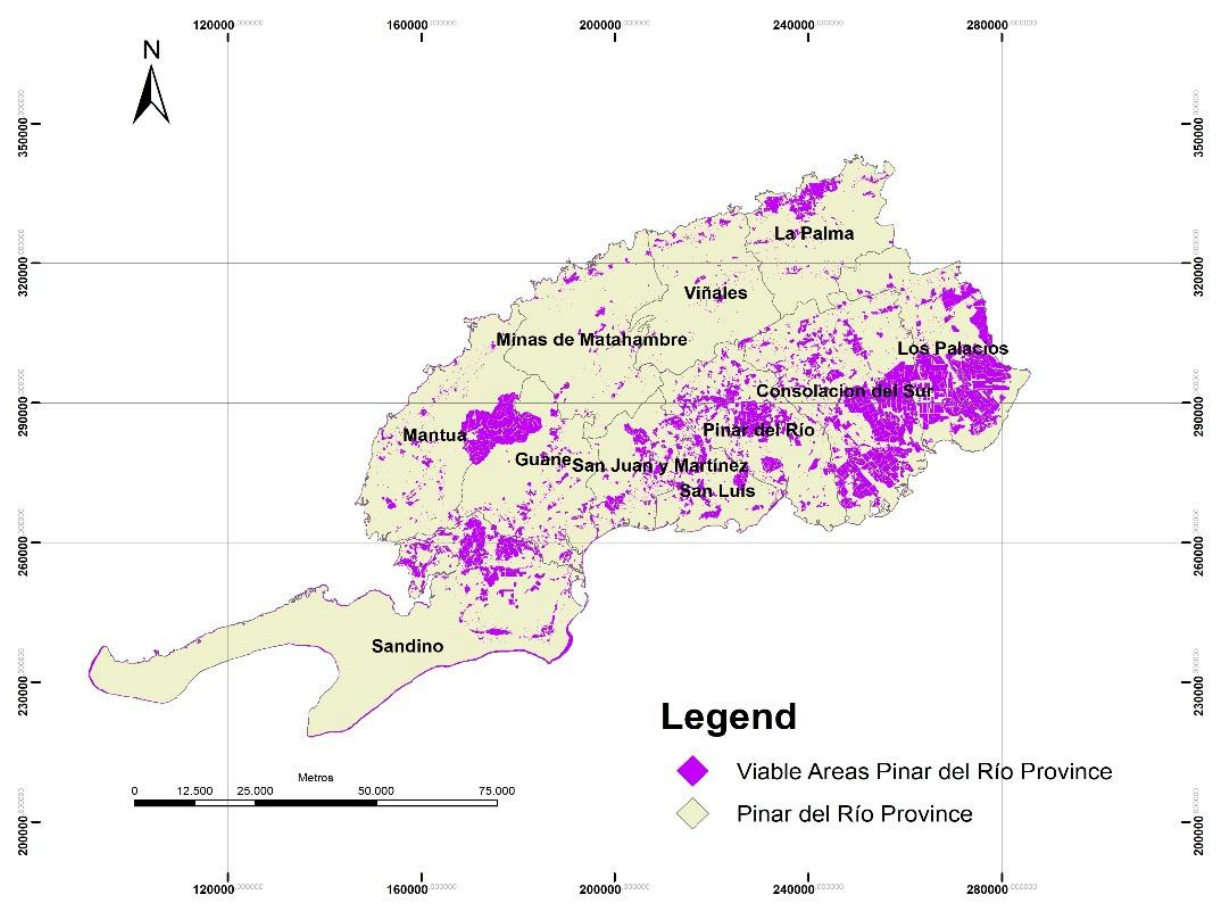

Figure 2. Map with viable areas to develop photovoltaic systems connected to the grid

It is important to highlight that in these areas populated areas were considered as viable areas for the installation of the systems since the roofed surfaces of the buildings, wasteland and other available areas can be used. Considering that only $0.3 \%$ of the viable areas studied, can be used for the installation of photovoltaic systems connected to the network, about 132.7 MWp with Photovoltaic Systems (SFV) could be installed in the province's territory. Based on these considerations and the data published by SWERA in 2005 regarding solar radiation, the annual average daily solar radiation map that affects the province was prepared. Table 1 shows the analysis of the specific impacts that could be produced by the installation of $1 \mathrm{MWp}$ of photovoltaics in the energy, economic orders for discontinued consumption of oil and environmental issues from the greenhouse gases that are no longer emitted to the atmosphere. The influence of the quality of solar radiation on the technical performance of the systems can be observed.

Table 1

Specific impacts that the installation of $1 \mathrm{MWp}$ of photovoltaic could produce

\begin{tabular}{llllll}
\hline Municipalities & $\begin{array}{l}\text { Annual } \\
\text { average daily } \\
\text { solar radiation } \\
\left(\mathrm{kWh} / \mathrm{m}^{2} \mathrm{día}\right)\end{array}$ & $\begin{array}{l}\text { Specific } \\
\text { productivity } \\
(\mathrm{kWh} / \mathrm{kWp})\end{array}$ & $\begin{array}{l}\text { Estimated } \\
\text { energy in } \\
\text { one year } \\
(\mathrm{kWh})\end{array}$ & $\begin{array}{l}\text { Economic } \\
\text { savings from oil } \\
\text { consumption } \\
(\text { USD) }\end{array}$ & $\begin{array}{l}\text { GHGs stopped } \\
\text { emitting into the } \\
\text { atmosphere (tn) }\end{array}$ \\
\hline Consolación del Sur & 5,560 & 1538,52 & 1539 & 211931,57 & 1153,89 \\
Guane & 5,529 & 1529,95 & 1530 & 210749,94 & 1147,46 \\
La Palma & 5,593 & 1547,65 & 1548 & 213189,43 & 1160,74 \\
Los Palacios & 5,804 & 1606,04 & 1606 & 221232,16 & 1204,53 \\
Mantua & 5,619 & 1554,85 & 1555 & 214180,48 & 1166,14 \\
Minas de Matahambre & 5,635 & 1559,28 & 1559 & 214790,36 & 1169,46 \\
Pinar del Río & 5,468 & 1511,96 & 1512 & 208272,32 & 1133,97 \\
San Juan y Martínez & 5,464 & 1511,96 & 1512 & 208272,32 & 1133,97 \\
San Luis & 5,337 & 1476,82 & 1477 & 203431,43 & 1107,61 \\
Sandino & 5,635 & 1559,28 & 1559 & 214790,36 & 1169,45 \\
Viñales & 5,585 & 1545,44 & 1545 & 212884,50 & 1159,08 \\
Promedio provincia & 5,600 & 1549,59 & 1550 & 213456,25 & 1162,19 \\
\hline
\end{tabular}


The term landscape can be conceptualized as a territorial system composed of complex components of different ranks, formed under the influence of natural processes and the modifying activity of human society, which are in permanent interaction and that develops historically (Cuba, 1987). In the analysis of feasibility studies for the installation of energy generating systems, the environmental effects produced by both traditional and renewable energies must be accompanied by the review of most of the parameters that determine the characteristics of the territory on that the generation infrastructures settle (Cuba, 1987). If we incorporate the use of solar energy in the inventories of environmental conditions due to the introduction of these technologies, the landscape element is detected immediately, because some of the infrastructure necessary for the production of this type of energy, affect Direct with the landscape variable.

It can be considered that technologies related to the use of solar energy are not the most aggressive. From the anthropogenic point of view and to the landscape, you can select those actions that will directly affect the environmental variables and in this way perform the analyzes to adopt the necessary measures, which mitigate and modify their effects. The result will be aimed at harmonizing the variables and making investment sustainable (Rodríguez, 2011). In the construction phase, it is usually necessary to clear and clean the surface of the installation, as well as earthworks caused by road construction, work tracks, and construction of buildings necessary for the infrastructure of the facilities, behaving as affectations to the landscape environment. It is also the creation of temporary construction facilities, as well as air pollution generated by heavy machinery traffic, gas emission, and noise pollution. It is considered that the impacts on this type of facility in the construction phase are minimal and not very representative of the effects on the landscape.

Other impacts occur during the operational stage, such as permanent land use; impact on the landscape variable caused by the visual intrusion of a surface covered by solar panels, of regular geometric shapes and very different color aspects of the environment; light pollution caused by the reflection that sunlight originates on the crystals that cover the devices, affecting these aspects to potential observers; as well as the transportation system that is based on the posts and cable trays necessary for the use of the energy produced by the power generation system. The relationships between the use of sunlight and landscape can mitigate its impact and achieve a sustainable and harmonious relationship with the environment and the territory. The introduction of these technologies may represent a modification of the landscape, which may cause alterations; but that does not give rise to a new landscape system, with photovoltaic energy being one of the most respectful signs to show the landscape vision. Unlike traditional energy systems, the technological equipment that is incorporated can be perfectly harmonized with the natural attributes of the landscape, the impact can be managed in a controlled manner at specific sites or locations and its exploitation is not predisposed to generate irreversible impacts on the landscape perspective; It is considered important to assume that the advantages of their economic meaning and the improvement of the quality of life represented by the introduction of these systems are justified for the benefit of society.

\section{Conclusions}

Applying the techniques of land management, it was possible to verify that in the province of Pinar del Rio there are possibilities from the technical point of view, for the development of the photovoltaic systems connected to the network. With the results obtained, it was determined that only with the use of $0.3 \%$ of the viable areas studied, 132.7 MWp of photovoltaic systems connected to the grid could be installed in the Pinar del Río province.

\section{References}

Arauz, W. M. S., Cedeño, G. I., Chávez, S. S., Pérez, A. V., \& Gámez, M. R. (2017). Microgrid with a 3.4 kWp photovoltaic system in the Universidad Técnica de Manabí. International Journal of Physical Sciences and Engineering, 1(2), 11-20. https://doi.org/10.21744/ijpse.v1i2.34

Arauz, W. M. S., Gamez, M. R., Perez, A. V., \& Fernandez, M. C. (2016). Microgrids views from a geographic information system. International Research Journal of Engineering, IT \& Scientific Research, 2(11), 57-65

BOE. (2004). Ley 4/2004, de 30 de Junio, de Ordenación del Territorio y Protección del paisaje. D.O.G.V. no 4788, de 2 Junio de 2004; BOE no 174, 20 de Junio de 2006 (España), 2.

Borges, C. L., \& Falcao, D. M. (2006). Optimal distributed generation allocation for reliability, losses, and voltage improvement. International Journal of Electrical Power \& Energy Systems, 28(6), 413-420. https://doi.org/10.1016/j.ijepes.2006.02.003 
Castillo, G. A. L., Albuerne, Y. E. L., Fernández, M. C., \& Alava, L. A. C. (2016). General information about the design of smart grids in universities. International Research Journal of Engineering, IT \& Scientific Research, 2(9), 59-66

Cuba., C. d. N. (1987). Paisaje, términos y definiciones. $N C$.

Ghosh, S., Ghoshal, S. P., \& Ghosh, S. (2010). Optimal sizing and placement of distributed generation in a network system. International Journal of Electrical Power \& Energy Systems,32(8), 849-856. https://doi.org/10.1016/j.ijepes.2010.01.029

Hachem, C., Athienitis, A., \& Fazio, P. (2011). Parametric investigation of geometric form effects on solar potential of housing units. Solar Energy, 85(9), 1864-1877. https://doi.org/10.1016/j.solener.2011.04.027

Hwang, I. H. (1997). Application of photovoltaic systems for rural electrification at remote Islands. Solar energy materials and solar cells, 47(1-4), 295-302. https://doi.org/10.1016/S0927-0248(97)00052-4

Keller, L., \& Affolter, P. (1995). Optimizing the panel area of a photovoltaic system in relation to the static inverter-Practical results. Solar Energy, 55(1), 1-7. https://doi.org/10.1016/0038-092X(95)00032-M

Leeuwen, A. V. (2001.). Ordenamiento Territorial: Un proceso participativo, sostenible y de democratización. Proyecto Información sobre Tierras y Aguas para un Desarrollo Agrícola Sostenible.(GCP/RLA/126/JPN.).

Mantuano, J. L. S., Vera, M. J. C., \& Cedeño, E. N. (2019). Factors of photovoltaic system cost affect in Ecuador. International Research Journal of Engineering, IT \& Scientific Research,5(6), 1-11. https://doi.org/10.21744/irjeis.v5n6.721

Mellit, A., \& Benghanem, M. (2007). Sizing of stand-alone photovoltaic systems using neural network adaptive model. Desalination, 209(1-3), 64-72. https://doi.org/10.1016/j.desal.2007.04.010

Niknam, T., Ranjbar, A. M., \& Shirani, A. R. (2003). Volt/Var control in distribution networks with distributed generation. IFAC Proceedings Volumes, 36(20), 547-552. https://doi.org/10.1016/S1474-6670(17)34526-3

ONE. (2007). Anuario estadistico de Cuba y sus territorio. Provincia de Pinar del Río. Oficina Nacional de Estadística, $C D$

ONU. (1992.). Agenda 21 de la ONU.

Peña, L. (2005.). Sistema de Información Geográfica: Herramienta para el Desarrollo Local Sostenible. Centro de Estudio de Desarrollo Agrario y Rural.

Pérez, A. V. P., Borges, C. G. R. B., \& Rodríguez, J. A. P. R. (2019). Photovoltaic system proposal for a house. International Journal of Physical Sciences and Engineering, 3(2), 34-43. https://doi.org/10.29332/ijpse.v3n2.330

Rodriguez. M. (2011). La ordenación y la planificación de las fuentes renovables de energía en la Isla de Cuba desde una perspectiva territorial. Estudio de caso en el municipio de Guama a partir de un Geoportal. Memoria presentada para obtener el Grado Científico de Doctora, Facultad de Humanidades, de la Universidaad Pablo de Olavides, Sevilla España.

Suarez, K. L. C., Carlos, A. G. J., Cuenca, L. A. S., Zambranod, J. A. G., \& Ponce, Ángel A. A. (2018). Demand in abdon calderon parish for possible installation of photovoltaic systems. International Journal of Physical Sciences and Engineering, 2(3), 62-69. https://doi.org/10.29332/ijpse.v2n3.218

SWERA. (2009). Solar and Wind Energy Resource Assessment (SWERA) SWERA Web Service.(http://na.unep.net).

Voivontas, D., Tsiligiridis, G., \& Assimacopoulos, D. (1998). Solar potential for water heating explored by GIS. Solar Energy, 62(6), 419-427. https://doi.org/10.1016/S0038-092X(98)00027-9 